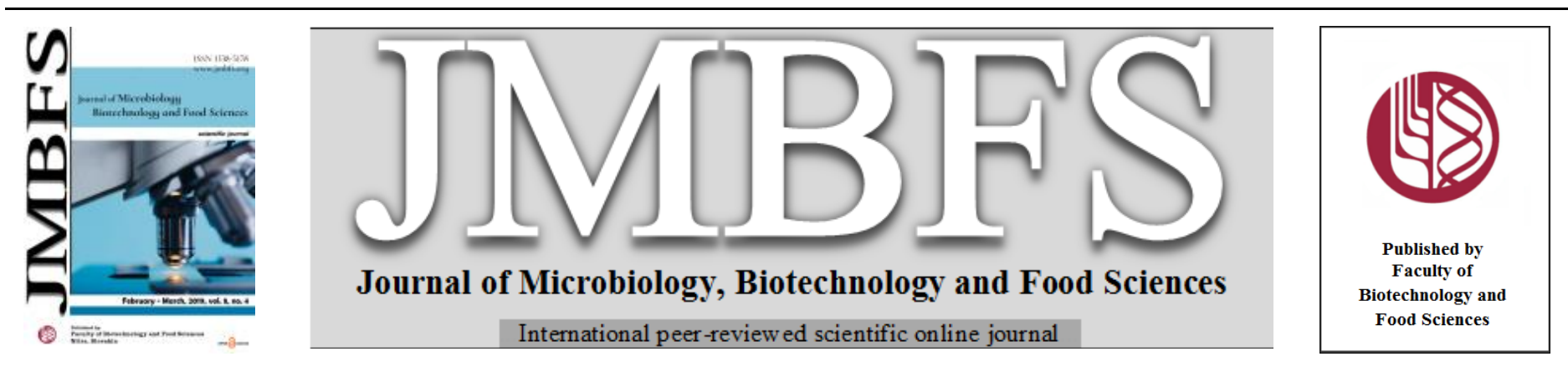

\title{
EVALUATION OF THE METROLOGICAL PARAMETERS OF METHODS FOR QUANTITATIVE DETERMINATION OF ACTIVE MICROBIAL STRAINS OF GENERA PSEUDOMONAS AND BACILLUS IN THE AIR OF BIOTECHNOLOGICAL PRODUCTION ZONE
}

\author{
Natalia Dudchik*1, Vasiliy Filanyuk ${ }^{2}$, Vitaliy Shevlyakov², Sergei Sychik ${ }^{2}$ \\ Address(es): Natalia Dudchik, \\ ${ }^{1}$ Republican Unitary Enterprise "The Scientific and Practical Center of Hygiene", Laboratory of Microbiology, Akademicheskaya street 8, 220012, Minsk, Republic of \\ Belarus. \\ ${ }^{2}$ Republican Unitary Enterprise "The Scientific and Practical Center of Hygiene", Laboratory of Industrial Toxycology, Akademicheskaya street 8, 220012, Minsk, \\ Republic of Belarus.
}

*Corresponding author: n_dudchik@tut.by, n_dudchik@mail.ru

doi: $10.15414 / j m b f s .2019 .8 .4 .1054-1056$

\section{ARTICLE INFO}

Received 6. 8. 2018

Revised 2. 11. 2018

Accepted 12. 11. 2018

Published 1. 2. 2019

Short communication

open 2 access

\section{ABSTRACT}

Provision of safety and sanitary-hygienic control of biotechnological processes poses a special medical-biological challenge requiring elaboration and metrological assessment of quantitative methods, which determine concentrations of microorganisms-producers in air of manufacturing zone in compliance with the criteria of the International Organization for Standardization. The results of experimental modeling of microbial sprays comprising bacteria of genera Bacillus and Pseudomonas in air of the production zone as the risk factor affecting health of bioindustry employees have enabled to calculate metrological parameters of methods to control microorganismsconstituents of monocomponent and bicomponent biological preparations. Such metrological parameters (standard deviation of repeatability, standard deviation of intermediate precision, expanded uncertainty) match the requirements set to the measurement methods at the accepted confidential probability level $\mathrm{p}=95 \%$ and ensure proper control of biotechnological processes.

Keywords: Microbial producers, Model experiment, Hygienic standards, Metrological characteristics

\section{INTRODUCTION}

One of rapidly developing trends of industrial biotechnology is manufacturing of microbial preparations to carry out biological control of diseases and to raise harvests of agricultural crops (Filanyuk et al., 2018). However, biotechnological processes may be accompanied by contamination of production media with microbial strains further released into the air of the operation zone and surrounding atmosphere, with the subsequent deleterious impact on the health of the staff and local population. Contact with microbial sprays is a grave risk factor for personnel of biotechnological plants, because industrial strains possess a pronounced sensitizing capacity (Budanov, et al., 2010, Ivanov et al., 2007; Pivovarov et al., 2010; Rüdel et al., 2009; Rakhmanin et al., 2001; Sergeyuk et al., 2003; Sheina et al., 2005; 2010; 2010; 2016; 2017). Comprehensive toxicological and hygienic investigations conducted in Republic of Belarus included assessment of immunoallergological, hematological, dysbiotic and disseminating parameters and established hygienic standards and maximum permissible concentrations for over 100 microbial strains-producers in the air of the working zone (Filanyuk et al., 2018; Shevlaykov et al., 2013, 2013, 2014) Effective control of biotechnological processes is grounded on application of validated instrumental methods for quantitative estimation of microbial concentrations. It is of principal significance that the technique evaluating the microbial cell titer in the air of the working zone must be developed, metrologically validated and approved before launching biotechnological process. It was shown earlier that laboratory modeling of microbial sprays at different levels of air contamination is a promising technology for elaboration of relevant quantitative determination methods, collection of statistical data, and computation of metrological parameters of the methods (Dudchik et al., 2016; Filanyuk et al., 2018, 2015). Development of standardized and validated methods to measure concentrations of microbial strains-producers is a rather complicated analytical task taking into account numerous parameters of instrumental method (air sampling at various microbial contamination levels, diverse cultural conditions and identification procedures, etc.). Algorithms for calculating metrological characteristics of methods evaluating microbial status have been developed for such matrices as aquatic media, food products and have not been formulated so far for metrological parameters of measurements quantifying biological factor in air media (ISO/TS 19036, ISO 5725- 2).
It appears logical therefore, that this study was aimed at evaluation of operational characteristics of the methods for quantitative determination of microorganisms from genera Pseudomonas and Bacillus in the air of biotechnological manufacturing area based on massive experimental data modeling generation of microbial sprays in simulation chambers. The research was carried out in accordance with guidelines of good laboratory practice (GLP) and International Organization for Standardization (ISO) standards.

\section{MATERIAL AND METHODS}

Active microbial strains-producers

Bacillus subtilis M-22 (BIM-439D), Pseudomonas fluorescens S 32 Pseudomonas aurantiaca B-162/255.17, Bacillus sp. BB58-3 were chosen as objects of studies. The cultures are deposited at Belarusian collections of nonpathogenic microorganisms.

\section{Microbial sprays modelling}

The system generating liquid sprays in 250 liter chambers for toxicological trials (Spectrolab, Russia); aspirator SAS SUPER100 (PBI International, Italy), and standard equipment of microbiological laboratories were engaged in our investigations. Measuring devices and instruments were duly verified and calibrated. Phosphate buffer solution containing $0.1 \%$ peptone, $\mathrm{pH} 7.0$, was used to prepare working dilutions of microbial preparations. Bacterial suspension with cell concentration of $1 \times 10^{6} \mathrm{CFU} / \mathrm{ml}$ was applied in microbial spray modeling experiments. Simulation of microbial sprays was performed using special chamber software. The volume of air samples varied in the range 10-50 liters depending on the concentration of microorganisms in the chamber. The samples collected in duplicate by aspiration technique were plated on the surface of the optimized agar media and incubated during $(48 \pm 2) \mathrm{h}$ at $(30 \pm 0.5)^{\circ} \mathrm{C}$. Culturalmorphological peculiarities of the grown colonies were characterized and the typical colonies were counted. 


\section{Calculation of microorganisms concentration in the working area}

Concentration of microorganisms $\mathrm{X}, \mathrm{CFU} / \mathrm{m} 3$ was calculated according to the following formula Equation (1):

$\mathrm{X}=(\mathrm{N} \times 1000) / \mathrm{V}$,

where:

$\mathrm{X}$ - concentration of microbial cells and spores in the air of the working zone; $\mathrm{N}$ - the number of microbial colonies on Petri plate;

1000 - conversion coefficient per $1 \mathrm{~m} 3$ of air;
V - volume of the sample, dm3.

\section{RESULTS AND DISCUSSION}

Microorganisms representing genera Bacillus and Pseudomonas find relatively wide use as biological promoters of growth and development of agricultura crops and biological control agents (Table 1) (Dudchik et al., 2016; Filianuk et al., 2018; 2015; Shevlaykov et al. 2013; 2013; 2014). The promising microbial strains are presented and briefly characterized in Tab. 1 .

Table 1 Main characteristics of active microbial strains

\begin{tabular}{|c|c|c|}
\hline Biological function & Strain properties and depository & $\begin{array}{c}\text { Sanitary-hygienic } \\
\text { standards for the } \\
\text { air of } \\
\text { manufacturing } \\
\text { zone }\end{array}$ \\
\hline $\begin{array}{l}\text { Biological control of } \\
\text { clamp rot in sugar } \\
\text { beet }\end{array}$ & $\begin{array}{l}\text { Strain Bacillus subtilis M-22 (BIM-439D) was deposited at collection of non- } \\
\text { pathogenic cultures, Institute of Microbiology, National Academy of Sciences of } \\
\text { Belarus. The strain shows antagonistic activity against phytopathogenic } \\
\text { microbiota }\end{array}$ & $1000 \mathrm{CFU} / \mathrm{m}^{3}$ \\
\hline $\begin{array}{l}\text { Stimulation of growth } \\
\text { and development of } \\
\text { cultivars }\end{array}$ & $\begin{array}{l}\text { Strain Pseudomonas fluorescens S } 32 \text { is a natural soil microorganism deposited at } \\
\text { collection of department of molecular genetics, Belarusian State University. The } \\
\text { strain is capable to colonize plant rhizosphere and vegetative system, causing a } \\
\text { considerable favorable effect on growth and development of agricultural crops }\end{array}$ & $1500 \mathrm{CFU} / \mathrm{m}^{3}$ \\
\hline $\begin{array}{l}\text { Biological control and } \\
\text { growth stimulation of } \\
\text { farm crops }\end{array}$ & $\begin{array}{l}\text { Strain Bacillus } s p \text {. BB58-3 derived by induced mutagenesis from natural strain } \\
\text { Bacillus sp. is antagonistic toward a broad spectrum of phytopathogenic fungi, } \\
\text { not phytotoxic, promotes growth of agricultural crops. Strain Pseudomonas } \\
\text { aurantiaca B-162/255.17 was produced by multistep mutagenic treatment of } \\
\text { wild-type bacterial strain. It was deposited at collection of department of } \\
\text { molecular genetics, Belarusian State University }\end{array}$ & $5000 \mathrm{CFU} / \mathrm{m}^{3}$ \\
\hline $\begin{array}{l}\text { Degradation of field } \\
\text { stubble and straw, } \\
\text { suppression of } \\
\text { pathogenic microbiota } \\
\text { and soil for } \\
\text { preconditioning } \\
\text { sowing campaign }\end{array}$ & $\begin{array}{l}\text { Strain Bacillus sp.-49 obtained by the selective procedure from enrichment } \\
\text { culture is not zoopathogenic, not phytopathogenic. It displays high antimicrobial } \\
\text { and cellulolytic activities. Strain Pseudomonas sp.-11 isolated from natural } \\
\text { sources is not zoo- and not phytopathogenic, shows elevated cellulolytic and } \\
\text { antimicrobial activities and ability to colonize plant rhizosphere and vegetative } \\
\text { tissues. Both strains are maintained at collection of industrial microbial strains, } \\
\text { Belarusian State University. }\end{array}$ & $5000 \mathrm{CFU} / \mathrm{m}^{3}$ \\
\hline
\end{tabular}

The technology designed for quantitative determination of microbial strains in the air of the production zone during model experiment is grounded on the classical stages and techniques of microbiological practice: air sampling by aspiration method taking into account the volume of the collected sample, microbial culture under optimal conditions, enumeration of grown colonies with typical morphological traits, identification of microorganisms and colonies, quantification of microorganisms on the plates followed by reconversion of the counted number per $1 \mathrm{~m}^{3}$ of air.

For metrological validation of applied measurement methods their operationa characteristics were estimated in conformity with ISO guidelines: determination of precision values (repeatability and intermediate precision with a variable operator factor), parameters of expanded uncertainty and the others (Pivovarov et al, 2010, Rudel et al, 2009).

Results of $\mathrm{p}=15$ series, each composed of $\mathrm{n}=2$ single measurements were engaged in computation. Homogeneity of dispersion was verified in compliance with Cochran's criterion. Cochran's test statistics parameter $\mathrm{Cr}$ was calculated according to the Equation (2):

$C r=\frac{\operatorname{MAX}\left[\left(y_{i 1}-y_{i 2}\right)^{2}\right]}{\Sigma_{i=1}^{p}\left(y_{i 1}-y_{12}\right)^{2}}$,

where

$\mathrm{i}$ - measurement series index, $\mathrm{i}=1, . ., p,(p=15)$

$y_{\mathrm{i} 1}, y_{\mathrm{i} 2}-$ measurement results, expressed in $\log _{10} \mathrm{CFU} / \mathrm{m}^{3}$ values in line with the Equation (3):

$y_{\mathrm{i} 1}=\log _{10} x_{\mathrm{i} 111 ;} y_{\mathrm{i} 2}=\log _{10} x_{\mathrm{i} 121}$

The obtained test-statistics parameter $\mathrm{Cr}$ was compared with the Cochran's critical value $\mathrm{C}(\nu=2 ; f=15 ; P=95 \%)=0.471$.

Provided the Inequation (4)

$\mathrm{C}_{\mathrm{r}}<\mathrm{C}(v=2 ; f=15 ; P=95 \%)$

is valid it was assumed that statistical divergence and overs wings could be neglected.

Standard deviation of repeatability was estimated using the Equation (5):
$S_{r}=\sqrt{\sum_{i=1}^{p} \frac{\left(y_{i 1}-y_{i 2}\right)^{2}}{2 \times p}}$

The value of repeatability limit $r, \mathrm{CFU} / \mathrm{m}^{3}$ was computed by the Equation (6)

$r=2,8 \mathrm{Sr}$

Calculation of standard deviation of intermediate precision was conducted according to the Equation (7):

$S_{i(T O)}=\sqrt{\sum_{i=1}^{n} \frac{\left(y_{i a}-y_{i b}\right)^{2}}{2}}$,

where

$\mathrm{Y}_{\mathrm{n}}-$ measurement results expressed in $\log _{10} \mathrm{CFU} / \mathrm{m}^{3}$

$\mathrm{i}$ - index of the sample, $\mathrm{i}=1$..n $(\mathrm{n}=15)$

$\mathrm{a}, \mathrm{b}-$ index of operator factor, $\mathrm{A}$ or $\mathrm{B}$

The limit of intermediate precision $r_{L(O)}, \log _{10} \mathrm{CFU} / \mathrm{m}^{3}$, was determined by the Equation (8):

$r_{L(O)}=2,8 \cdot \mathrm{S}_{I(O)}$

Uncertainty of measurement was assessed in conformity with ISO/TS 19036; ISO 5725-2 standards

Expanded uncertainty $U$ with span coefficient 2 (approximately corresponding to confidential probability value $95 \%$ ) was calculated according to the Equation (9)

$U=2 \times S_{I(o)}$

where

$S_{l(O)}$ - standard deviation of intermediate precision, $\log _{10} \mathrm{CFU} / \mathrm{m}^{3}$

Massive data collected in model experiments allowed to evaluate metrological characteristics of the methods (Tab. 2). 
Table 2 Metrological characteristics of the quantitative determination methods

\begin{tabular}{lccc}
\hline & & Values, $\log _{10} \mathrm{CFU} / \mathrm{m}^{3}$ & \\
\cline { 2 - 4 } Metrological parameters & $\begin{array}{c}\text { Pseudomonas aurantiaca } \\
\text { B-162/255.1 } \\
\text { Bacillus sp. BB58-3 }\end{array}$ & $\begin{array}{c}\text { Bacillus subtilis } \\
\text { M-22 }\end{array}$ & Pseudomonas fluorescens S32 \\
\hline Standard deviation of repeatability $S_{r}$ & 0.012 & 0.039 & 0.088 \\
\hline Repeatability limit $r$ & 0.034 & 0.111 & 0.253 \\
\hline $\begin{array}{l}\text { Standard deviation of intermediate } \\
\text { precision } \mathrm{S}_{l(O))}\end{array}$ & 0.147 & 0.052 & 0.124 \\
\hline $\begin{array}{l}\text { The limit of intermediate precision } \\
r_{l(O)}\end{array}$ & 0.411 & 0.152 & 0.324 \\
\hline Expanded uncertainty $(\mathrm{k}=2) U$ & 0.303 & 0.112 & 0.232 \\
\hline
\end{tabular}

\section{CONCLUSION}

Model experiments simulating generation of microbial sprays resulted in representative data enabling to estimate metrological characteristics of the methods for quantitative determination of concentrations of strains Pseudomonas aurantiaca B-162 / 255.17, Bacillus sp. BB58-3 and Pseudomonas fluorescens $\mathrm{S} 32$ in the air. It has been confirmed that the methods provide for strict sanitary control of microbial cell concentrations in the production zone to meet the established hygienic standards. Approaches were formulated to calculation of metrological parameters of quantitative determination methods controlling the level of microorganisms in the air of the work zone as a potential risk factor threatening health of personnel employed in biotechnological industry.

Acknowledgements: The authors express sincere gratitude to colleagues of the Belarusian State Institute of Metrology of the State Committee for Standardization of the Republic of Belarus.

\section{REFERENCES}

Budanova, E. V., Sheina, N. I., Skriabina, E. G., Ivanov, N. G., Vorob'ev, A. A., Zverev, V. V. (2010). Comparative studies of microbial strains used in biotechnology for the elaboration of biosafety standards. Vestnik Rossiiskoi Akademii Meditsinskich Nauk, 11, 42-6 (in russian).

Dudchik, N. V., Filanyuk, V., Shevlyakov, V. V., Sychik, S. I., Studenichnik, T.S. (2016). Development and validation of methods for measuring singlecomponent microbial preparations based on strain Bacillus and Pseudomonas in the working area. Actualnye Problemi Transportnoi Mediciny, 4, 21-9 (in russian)

Filanyuk, V. A., Shevlyakov, V. V., Dudchik, N. V. (2018). Methodology of microbial preparations hygienic regulation and methods of measurements microorganisms content in the working zone air. Minsk : Transtekhnika, $264 \mathrm{p}$ ISBN 978-985-7110-26-1 (in russian).

Filanyuk, V. A., Shevlaykov, V. V., Dudchik, N. V., Erm, G. I., Ushkov, A. A (2015). Development of hygienic standard and the method of controlling air content of the combined microbial product "Profibakt-fito". Medical Journal, 4, 128-36. (in russian).

ISO/TS 19036. Microbiology of food and animal feeding stuffs - Guidelines for the estimation of measurement uncertainty for quantitative determinations. https://www.iso.org/standard/38948.html

ISO 5725-2. Accuracy (trueness and precision) of measurement methods and results - Part 2: Basic method for the determination of repeatability and reproducibility of a standard measurement method. https://www.iso.org/standard/11834.html

Ivanov, N. G., Sergeyuk, N. P., Sheina, N. I., Skriabina, E. G., Budanova, E. V. (2007). Maximum permissible concentrations of the microorganisms-producers, bacterial preparations and their components in the ambient and workplace air. M., Federal Centre for Hygiene and Epidemiology (in russian).

Pivovarov, Yu. P., Sheina, N. I., Ivanov, N. G., Korolik, V. V., Skriabina, E. G. (2010). Problems and perspectives of the hygienic regulation of biotechnological strains of microorganisms. Gigiena i Sanitaria, 5, 9-12 (in russian).

Rudel, H., Schroder, W., von der Trenck, K. T., Wiesmüller, G. A. (2009) Chemical and biological environmental monitoring series. Preface. Environmental Science and Pollution Research, 16(5), 483-5. http://dx.doi.org/10.1007/s11356-009-0192-7

Rakhmanin, Yu. A., Bagdasarjan, G. A., Nemirya, B. I., Sergeyuk, N. P. (2001). Basic approaches to regulation of biological contaminants. Gigiena i Sanitaria, 1, 6-9 (in russian).

Sergeyuk, N. P., Suprun, I. P., Buyanov, V.V. (2003). Sanitary and epidemiological regulation of the industrial microorganisms. M.: Chernogolovka. Sheina, N. I., Skriabina, E. G., Ivanov, N. G. (2005). Comparative characteristics of immunotropic action of industrial strains of microorganisms for their hygienic standardization. Toxicologitcheskii Vestnik, 3, 12-5 (in russian).

Sheina, N. I., Zholdakova, Z. I., Ivanov, N. G. (2010). Problem in the hygienic regulation and standardization of biotechnological strains in reservoir water. Gigiena i Sanitaria, 5, 39-42 (in russian).
Sheina, N. I., Ivanov, N. G. (2010). Investigation of biotechnological strains of microorganisms for their hygienic standardization. Gigiena i Sanitaria, 2, 89-92 (in russian).

Sheina, N. I., Ivanov, N. G. (2010) Scientific basis for hygienic classification of risk caused by microorganisms applied in biotechnologies. Meditsina Tryda i Promishlennaya Ekologia, 5, 1-5 (in russian).

Sheina, N. I., Skryabina, E. G., Pivovarov, Yu. P., Budanova, E. V., Myalina, L. I., Korolik, V. V., Kolesnikova, V. V., Sazonova, L. P., Chub, G. G. (2016) Industrial microorganisms biosafety problem in Russia: present and future. Toxicologitcheskii Vestnik, 4, 2-10 (in russian).

Sheina, N. I., Budanova, E. V., Pivovarov, Yu. P., Mjalina, L. I., Sazonova, L. P. (2017). Biosafety assessment of microbial strains used in biotechnology according to their taxonomy. International Journal of Biomedicine 7(1), 51-6. http://dx.doi.org/10.21103/Article7(1) OA6

Shevlaykov, V. V., Filanyuk, V. A., Studenichnik, T. S., Erm, G. I., Dudchik, N. V. (2013). Hygienic regulations of the microbial medication "Stimul" content in the working area air. Medical Journal, 4, 135-9 (in russian).

Shevlaykov, V. V., Filanyuk, V. A., Erm, G. I., Tchernischova, E. V., Ushkov, S. A., Buynickaya, A. V., Studenichnik, T. S. (2014). On the methodology of hygienic regulation of microorganisms-producents and microbial compositions in the workplace air. Medical Journal, 2, 40-53 (in russian)

Shevlaykov, V.V., Filanyuk, V. A., Studenichnik, T. S., Erm, G. I., Dudchik, N. V. (2013). Substantiation of the maximum allowable concentration (MAC) in the working area's air of the microbial medication Betaprotectine. Medical Journal, 2, 123-6 (in russian). 